\title{
Историко-философский экскурс
}

DOI: $10.30727 / 0235-1188-2020-63-12-81-101$

Оригинальная исследовательская статья

Original research paper

\section{«Катхаваттху» («Вопросы дискуссии») как первоисточник раннебуддийской философии}

\author{
А.В. Ложкина \\ Институт философии РАН, Москва, Россия
}

\section{Аннотация}

Статья посвящена малоизученному раннебуддийскому тексту «Катхаваттху» («Вопросы дискуссии»). Автор стремится ответить на главный вопрос о том, в чем состоит значимость «Катхаваттху» для истории философии. В процессе исследования, чтобы приблизиться к ответу на него, автор последовательно рассматривает историю сложения «Вопросов дискуссии», особенности текста и его краткое содержание. «Вопросы дискуссии» предлагается рассматривать не изолированно, а в качестве памятника, чья структура связана с характеристиками палийского канона как единого целого, состоящего из разнородных текстов. Ставится также проблема перевода палийских религиозно-философских текстов. Выделена проблема принадлежности «Катхаваттху» Абхидхамма-питаке и влияния этого на способ философствования, принятый в анализируемом тексте. Предметом настоящей статьи является историко-философское содержание «Катхаваттху». Основной тезис сформулирован следующим образом: историко-философское содержание текста последовательно раскрывается в обсуждении спорных для школ раннего буддизма вопросов. В начале текста расположены наиболее значимые для раннего буддизма вопросы (о субъекте-пудгале, о достигшем совершенства - apxa$m e)$. По мере приближения к концу текста значимость обсуждаемых вопросов убывает. В заключительной части памятника древнеиндийской философии содержатся наиболее поздние вопросы. Обсуждение в каждом вопросе зависит от логического метода восьми опровержений, использования списков-матик и позиции школы тхеравада, которой принадлежит окончательная редакция текста. Отдельное место в статье уделено определению жанра «Катхаваттху». Автор предлагает считать жанр этого произведения уникальным примером религиознофилософского диалога в раннебуддийской литературе. 
Ключевые слова: ранний буддизм, тхеравада, Абхидхамма-питака, палийский канон, индийская философия.

Ложкина Анастасия Витальевна - кандидат философских наук, младший научный сотрудник сектора восточных философий Института философии РАН.

lozhkinaanastasiya@yandex.ru

https://orcid.org/0000-0003-3289-1736

Для цитирования: Ложкина А.В. «Катхаваттху» («Вопросы дискуссии») как первоисточник раннебуддийской философии // Философские науки. 2020. Т. 63. № 12. С. 81-101.

DOI: $10.30727 / 0235-1188-2020-63-12-81-101$

\title{
Kathāvatthu ("Points of Controversy") as a Primary Source of Early Buddhist Philosophy
}

\section{A.V. Lozhkina}

Institute of Philosophy, Russian Academy of Sciences, Moscow, Russia

\begin{abstract}
This article focuses on the under-researched Buddhist text Kathāvatthu ("Points of Controversy") and aims to better determine its place within Indian philosophy. We consider how the text was compiled, its contents, and main characteristics (such as its genre, its classification lists - mätika) To understand some of those characteristics, we suggest viewing them as shared with the whole Pāli Canon (a large body of heterogeneous texts, of which the Kathāvatthu is part). This article also illustrates the issues of translating religious and philosophical texts from the Pāli language. Particularly, we highlight that the Kathāvatthu belongs to the part of Pāli Canon known as the Abhidhamma Pitaka, and consider how this influences the philosophical discourse presented in this text. We analyze the historical and philosophical content of the Kathāvatthu. We argue that such content of this work is consistently revealed in the discussion of issues controversial for the schools of Early Buddhism. At the beginning of the text, there are the most significant questions for Early Buddhism (about the subject (pudgala), about the one who has reached perfection - arhat). As we get closer to the end of the text, the importance of the issues discussed diminishes. Its final part contains the latest questions. The discussion in each question depends on the logical method of the eight refutations, the use of lists (mattika), and the position of the Theravāda school to which the final version of the text belongs. In the article, special attention is paid to the determination of the Kathāvatthu genre. We
\end{abstract}


conclude that the genre of this work can be considered as a unique example of religious and philosophical dialogue in Early Buddhist literature.

Keywords: Early Buddhism, Theravāda, Abhidhamma pițaka, Pāli Canon, Indian philosophy.

Anastasiya V. Lozhkina - Ph.D. in Philosophy, Junior Research Fellow, Department of Oriental Philosophies, Institute of Philosophy, Russian Academy of Sciences.

For citation: Lozhkina A.V. (2020) Kathāvatthu ("Points of Controversy") as a Primary Source of Early Buddhist Philosophy. Russian Journal of Philosophical Sciences = Filosofskie nauki. Vol. 63, no. 12, pp. 81-101. DOI: 10.30727/0235-1188-2020-63-12-81-101

\section{Введение}

Речь в данной статье пойдет о классическом памятнике древнеиндийской философии - тексте «Вопросы дискуссии» («Катхаваттху»). Данный текст фиксирует дискуссии раннебуддийских школ рубежа до н.э. и н.э., а также первых веков н.э.

«Катхаваттху» является обширным компендиумом спорных для раннего буддизма вопросов, касающихся философской и религиозной сторон буддийской доктрины ${ }^{1}$. Каждая его часть (пали катха - «беседа», «обсуждение», «рассказ») посвящена взглядам отдельной школы раннего буддизма. Например, в первой главе рассмотрены взгляды школ пудгалавада и махасангхика. За один и тот же взгляд может выступать несколько школ, хотя чаще всего в комментаторской литературе принято выделять одну главную школу, которой приписывается обсуждаемая точка зрения. Существовавшие в раннем буддизме

${ }^{1}$ Из текстологических работ, посвященных «Вопросам дискуссии», в качестве самой глубокой и интересной нужно назвать книгу почт. Ньянатилоки [Nyanatiloka 2007]. Краткое содержание и анализ логического метода, применяющегося в тексте «Катхаваттху», приводит в своей отдельной статье C.Н. Дуббе [Dubbe 2005]. Начало «Вопроса о пудгале» рассмотрено в статьях Д. Бастоу [Bastow 1996], Дж.П. Дермотта [Dermott 1989] и Дж. Ганери [Ganeri 2001]. Наиболее полно обзор содержания «Катхаваттху» дан в книге А. Баруа [Barrua 2006]. Общие сведения о «Катхаваттху» можно найти и в книге А. Бхаттачарьи [Bhattacharya 2010]. К сожалению, исследовательская литература о «Катхаваттху» текстологическими работами исчерпывается. В настоящее время об этом тексте нет религиоведческих или историко-философских работ. Критическое издание текста было выполнено А.Ч. Тейлером [Kathāvatthu 1894-1897]. 

спорные вопросы собраны в единый текст с позиции школы тхеравада. Для того, чтобы школа могла признаваться авторитетной и имеющей право на существование, у нее должен быть собственный канон священных текстов. В палийский канон, соответственно, вошел текст «Вопросы дискуссии», представляющий собой абстрактную полемику, надстраивающуюся над реальными дебатами, возникающими между школами.

Вопросы, которые являлись для представителей школ раннего буддизма спорными, т.е. могли вызывать обсуждениекатха, составляли основу содержания (пали ваттху - «предмет», «основа») для текста источника. Проблема школ раннего буддизма, которая осмыслялась внутри буддизма на теоретическом уровне в виде отдельного учения о «школе» / философско-религиозном направлении (пали ачария-вада «учение учителей», пали никая - «часть», «отделение»), оказала сильное влияние на формирование «Вопросов дискуссии» [Ложкина 2019б].

При этом внутри буддизма не существовало резкого деления на ересь и ортодоксию. В индийской философии используется противопоставление «верные взгляды» (пали самма-диттхи) и «ложные взгляды» (пали миччха-диттхи), позволяющее фиксировать принадлежность школы кругу воззрений, согласных со Словом Будды (пали Буддха-вачана). В полемике представители раннебуддийских школ стремятся доказать, что взгляд оппонента относится к ложным взглядам, т.е. с буддийской точки зрения не отражает структуру реальности.

\section{История сложения «Вопросов дискуссии», основные особенности текста и его краткое содержание}

Трактат «Катхаваттху» («Вопросы дискуссии») является ценным источником для изучения философии школ раннего буддизма. Он сформирован школой тхеравада в виде текста, обладающего целостной структурой, на рубеже до н.э. и н.э.

«Катхаваттху», как и все тексты раннего буддизма, передавался в устной форме от учителя к ученику. Начало устного распространения не совпадает хронологически со временем его фиксации в форме канонического текста. К фиксации текста можно отнести оформление его структуры, а также выстраивание каркаса или рамки, позволяющей в дальнейшем вносить в текст изменения и дополнения. «Катхаваттху» рождается 


\section{А.В. ЛОЖКИНА. «Катхаваттху» («Вопросы дискуссиџ») как первоисточник...}

из обсуждения вопросов Учения между Буддой и учениками, бесед учителей-ачарий и буддийской общины. На буддийских соборах-спевках (пали сангити) происходит «сборка» текста в единое целое и унификация его языка.

Согласно ланкийским хроникам Моггалипутта Тисса рецитировал текст «Катхаваттху» на третьем буддийском соборе в Паталипутре (совр. Патна) спустя два века после нирваны Будды (около III века до н.э.). Эту дату принято считать датой составления текста [Points of Controversy... 1915, XXVII-XXVIII; Norman 1983, 103]. Интересно отметить, что для других текстов палийского канона не приводится дата составления и имя первого монаха, рецитировавшего текст. Это свидетельствует об уникальном месте «Вопросов дискуссии» в структуре палийского канона. Проблема авторства в древнеиндийский текстах отличается от современного понимания авторства. В отношении древних текстов мы вынуждены говорить о длительном формировании текста, выходящем за рамки одного поколения, и об условной (переосмысленной в рамках традиционного нарратива) фигуре автора.

Проблема датировки «Катхаваттху» связана с закономерностями передачи хронологических данных в буддийской традиции. Начальной точкой буддийской хронологии принято считать нирвану Будды. Датировка «Катхаваттху» связана с большим количеством внетекстовых факторов. Можно утверждать, что текстовое ядро памятника сложилось позднее традиционной даты (III век до н.э.) на несколько веков.

Помимо традиционной датировки в буддологических исследованиях применяется датировка «Вопросов дискуссии», которую можно назвать лингвистической. Сторонники этого подхода выделяют в пали черты, присущие среднеиндийскому языку магадхи. Существует гипотеза, что магадхи был языком, на котором вел проповедь сам Будда. К.Р. Норман полагает, что из-за присутствия магадхизмов «Катхаваттху» можно считать одной из древних частей палийского канона [Norman 1983, 104-105].

В колофоне к «Катхаваттху» указана принадлежность текста к литературе стиля пакарана, характерного для Абхидхаммапитаки. О стиле пакарана в исследовательской литературе сведений чрезвычайно мало. Жанр текста мы предлагаем определить как философско-религиозный диалог. 
На формирование текста «Вопросы дискуссии» оказали влияние уровни организации Учения катха и вада. Беседакатха представляет собой непосредственное обсуждение проблем и терминов раннебуддийской философии, зафиксированное в виде единого текстового целого. Учение-вада то, что также стремится отразить текст «Катхаваттху». Baдa представляет собой более строгое и выстроенное по правилам изложение доктрин раннебуддийских школ, затрагивающие все стороны буддийской философии и все дисциплинарные вопросы.

«Катхаваттху» - это компендиум спорных вопросов раннего буддизма. В современном критическом издании текста насчитывается около 250 вопросов. В буддийских традиционных источниках принято перечислять большее количество вопросов. Согласно «Диргха-никае» и позиции палийского комментатора Буддхагхоши (V век н.э.), 500 вопросов «Катхаваттху» являются ортодоксальными, 500 - неортодоксальными. Вероятно, это связано с тем, что состав памятника подвергался многочисленным редакциям вплоть до VII века н.э. Проблема соотношения канонического текста и комментария (пали тика и атххакатха) представляет собой отдельную тему. Например, для комментария Буддхагхоши характерны замены терминов на близкие по значению слова (термин «субъект-пудгала» он объясняет через «синонимы»: самость-аттха, сущность-сатта, жизненная сила-джива).

Текст «Катхаваттху» состоит из 23 разделов (пали вагга), в каждый из которых входит от пяти до двенадцати вопросов для обсуждения. Разделы-вагги объединяются в четыре более крупных текстовых блока (пали паннасака - «состоящее из $50 »)$. В каждый такой блок входит около 50 вопросов-катха [Hinüber 1996, 71]. Каждая беседа-катха построена в вопросноответной форме. При этом часто бывает сложно определить, кто из участников спора является противником, а кто - приверженцем тхеравады. Имена собеседников в тексте не приведены. Каждый из участников спора выступает как представитель обобщенной позиции своей школы. В комментарии Буддхагхоши на «Катхаваттху» к каждому вопросу текста приводится название школы, которой принадлежит та или иная позиция. Сегодня исследователи ориентируются на список Буддхагхоши. 


\section{Состав «Вопросов дискуссии»}

В 23 книгах «Катхаваттху» обсуждаются все важнейшие доктринальные и дисциплинарные проблемы раннего буддизма. Среди них - природа Будды и подношения ему, архат («достигший высшей цели» - человек, который достиг Просветления), нирвана, миряне, боги, причинность, карма, татхата («таковость», характеристика устройства мира в буддизме), Восьмеричный путь, этические вопросы и космология. Книги составлены в разное время, вплоть до разницы в несколько веков.

Первая глава «Катхаваттху» является самой большой в произведении. В переводе Каролины Рис-Дэвидс она занимает около 100 страниц, что в два раза больше объема остальных глав памятника. Первому вопросу первой главы - «Беседе о nудгале» («Пуггала-катха») - посвящено около 65 страниц в переводе Рис-Дэвидс. Остальные вопросы всех глав «Катхаваттху» представлены на пяти-десяти страницах. Объем текста указывает на важность обсуждения учения о субъекте-пудгале в раннем буддизме. Переводу данного вопроса и определению его места в раннебуддийской философии посвящена наша кандидатская диссертация [Ложкина 2019а]. В настоящей статье выделим другие значимые вопросы, входящие в «Катхаваттху» и демонстрирующие уникальность этого памятника.

После полемики о субъекте-пудгале в первой главе содержится несколько вопросов. Безусловно, важнейшие из них - вопросы о доктринах школ махасангхика и сарвастивада. Согласно раннебуддийским источникам махасангхика - это первая из раннебуддийских школ, выделившаяся из ранее неделимой общины-сангхи. Поводом для ее отделения стала особая трактовка основателем школы некоторых доктринальных и дисциплинарных вопросов. Эти воззрения получили название по имени основателя школы - пять пунктов Махадэвы. Главным из этих положений был взгляд, суть которого состояла в том, что достигший пробуждения, архат, может утрачивать состояние архатства и обладать несовершенствами. Этот вопрос обсуждается вторым в «Катхаваттху». Может ли архат не преодолевать некоторые омрачения - предмет другого обсуждения.

Обсуждение в дальнейших главах представлено в более детализированной форме. Вопросы об архатстве прослеживают его отношение к перерождению, благой заслуге (пуння), карме 
и смерти. В качестве иллюстрации приведем вопросы о том, обладает ли сознание архата, покидающего этот мир, качеством благости; в самом ли деле apxambl и Будды покидают этот мир в состоянии неподвижного транса.

К теме архатства примыкают вопросы о Благородном восьмеричном пути, ведущем к освобождению. Обсуждение Благородного восьмеричного пути затрагивает его связь с сознанием, телесностью и моралью. В других местах канона, насколько нам известно, не встречается альтернативная трактовка Благородного пути как состоящего из пяти частей (двадцатая глава).

Тема освобождения обсуждается в пятой главе памятника. Она раскрывается в связи с понятием «знание». Собеседников интересуют связь знания и освобождения, характер знания (относительное саммути-няна и абсолютное параматmха; аналитическое знание), возможность знания будущего и то, может ли ученик (севака) получить знание о вступлении на Путь от других людей. В обобщенном виде последний вопрос формулируется таким образом: «Можно ли влиять на сознание других людей?» (шестнадцатая глава). О взаимосвязи знания, состояния озарения и сознания говорится в одиннадцатой главе. Для раннего буддизма значимы были и вопросы о том, может ли мирянин преодолеть желание и страсть, происходит ли достижение пробуждения постепенно (вторая глава). Эти вопросы вызвали формирование нескольких школ.

Еще одна известная и широко распространенная школа раннего буддизма - сарвастивада. Ее положения обсуждаются в первой главе «Катхаваттху». В названии этой школы уже определен ее основной философский принцип - «все существует». Имеется в виду, что существуют не только дхаммы настоящего, но и дхаммы прошлого и будущего.

В содержании других глав «Катхаваттху» выделяются следующие вопросы. В первую очередь обратим внимание на вопрос о том, принадлежит ли Слово Будды земному или запредельному мирам. Понимание природы Будды как запредельной нашему миру характерно для поздних школ буддизма, в том числе школ направления махаяна. Разные возможности трактовки природы Будды заложены в ранних слоях буддизма. В текстах «Сутта-питаки» неоднократно указано, что Будда среди прочих необычных способностей обладал божественным 


\section{А.В. ЛОЖКИНА. «Катхаваттху» («Вопросы дискуссиџ») как первоисточник...}

видением, которое позволяло ему видеть мир целиком. Этот вопрос содержится в «Катхаваттху» (третья глава). Еще один вопрос о сверхординаторных способностях Будды входит в двадцать первую главу памятника. В ней спрашивают о том, могут ли Будда и его ученики магически менять любую вещь, имеют ли ученики Будды те сверхординаторные способности, которые имел он. В одиннадцатой главе памятника обсуждается близкий к этому вопрос о том, длится ли жизнь человека, обладающего сверхординаторными способностями, весь мировой период-кальпу. Махатхера Ньянатилока поясняет, что этот взгляд связан с ошибочной трактовкой понятия «кальпа» по «Махапариниббана-сутте» как мирового периода, а не как срока жизни [Nyanatiloka 1988, 100]. Помимо этого, к вопросам о природе Будды относится вопрос о его агиографии, о том, верно ли, что Будда на самом деле всегда жил на небесах Тушита, а на земле он воплотился в образе человека для проповеди Учения (восемнадцатая глава). Данный вопрос, по Ньянатилоке, имеет параллели с христианством [Nyanatiloka 2007, 109]. Необычна для буддизма трактовка вопроса о том, верно ли, что Будда не испытывает сострадания.

Будда, согласно самым древним текстам канона, наделен 32 лаккханами - признаками великого человека (скр. махаnypyma). Эти признаки могут принадлежать также великому царю. В «Вопросах дискуссии» представлен раздел, в котором обсуждается проблема, связанная с тем, достаточно ли обладание 32 лаккханами, чтобы быть Боддхисаттвой.

Исследователи выделяют в качестве определяющих развитие буддизма различные факторы. Л.Р. Фурцева пишет, что на направление развития буддизма в эпоху Кушан оказали влияние концепции благих заслуг и подаяния [Фурцева 1990, 20]. «Катхаваттху» не обходит эти вопросы стороной. Они сформулированы в седьмой главе следующим образом: «Является ли подаяние милостыни (данa) только ментальным действием, возрастает ли благая заслуга [от подаяния] вместе с радостью от подаяния?» В семнадцатой главе обсуждение становится более практическим. Собеседников интересует ряд вопросов о том, принимает ли сангха дары; подношения могут ли быть сделаны милостыней, едой и пр.; приносит ли дар сангхе такую же заслугу, как дар Будде; возможен ли дар, не одобренный получателем. 
Концепция, появившаяся в раннем буддизме и впоследствии ставшая очень значимой - понятие пустоты (пали суннята, скр. шуньята). Собеседники, как принято в Абхидхамме, обсуждают шуньяту согласно классификациям феноменов: 1) как относящуюся к ментальным факторам (санкхара-ккхандха) или не относящуюся к ним; 2) как обусловленную или необусловленную (санхата - асанкхата).

В «Катхаваттху» выделяется тема перерождения. Ее аспект связь перерождения и сознания, т.е. вопрос о том, могут ли перерождаться существа, не обладающие сознанием.

В шестой главе «Катхаваттху» центральной является тема причинности. Ранее, например, в вопросе о субъекте-пудгале, причинность использовалась только как один из списков-матик. Далее в обсуждение вводится дихотомия обусловленное - необусловленное. Необусловленное (пали асанкхата) буддисты понимают как то, что является несотворенным и вечным. Понятие «необусловленное» в «Вопросах дискуссии» предлагается определить через то, что может быть его подвидами. Варианты предлагаются такие: уверенность, обретенная с помощью прохождения четырех этапов Пути, само прохождение четырех этапов Пути, взаимозависимое возникновение (пали патиччасамуппада), четыре благородные истины, пространство.

Вопрос о причинности конкретизируется в одиннадцатой, пятнадцатой, шестнадцатой, двадцать третьей главах «Катхаваттху». В них автор спрашивает о том, обусловлены ли дхаммы и состояние непостоянства, связана ли причинность со временем, как расположены относительно друг друга звенья цепи взаимозависимого возникновения санкхара и неведенияавиджджа. Вопрос о том, могут ли быть связаны причинность и телесность, составляет еще один аспект этой темы. Вопрос о причинности разбирается по отношениюпр страданию-дуккхе и основным буддийским классификациям (5 скандx, 12 аятан, 18 дхату и 22 индрии). Значимо пересечение проблематики этого фрагмента с текстом «Паттхана». Его основная проблематикаразбор типов причин (пали паччая).

Помимо понятий «обусловленное» и «необусловленное» в тексте выделяется понятие «неопределенное» (авьяката) то, о чем мы не можем высказать определенного суждения. Например, в тексте обсуждается проблема о том, относятся ли к данной категории ложные взгляды (четырнадцатая глава). 
А.В. ЛОЖКИНА. «Катхаваттху» («Вопросы дискуссиш») как первоисточник...

С буддизмом и индийской философией часто связывают учение о карме. В раннем буддизме карму понимают как вызревание результатов деяний. В частности, текст ставит вопросы о том, являются ли старость и смерть результатами кармы и является ли земля результатом действия кармы (пали камма). Почт. Ньянатилока переводит данное понятие как «действие» [Nyanatiloka 2007, 149]. В общем виде представление о карме связано с производством результата от причины. В тексте поставлен вопрос о том, является ли намерение причиной (двенадцатая глава). Предпринята попытка определить карму как материальный или как ментальный феномен. Различные виды кармы анализируются в пятнадцатой главе. Интересный ракурс проблема приобретает в двадцать второй главе. В ней спрашивают, может ли карма создаваться во сне. Следует отметить, что тема кармы затрагивалась еще в «Вопросе о субъекте-пудгале», но в виде классификационного списка.

Вопросы о сознании и восприятии можно объединить в отдельную группу. Первым из них является вопрос о том, можно ли объединить одни ментальные состояния с другими (седьмая глава). В эту группу попадают вопросы о перинатальном сознании и существовании промежуточного состояния между двумя рождениями (антарабхава) (четырнадцатая глава).

К вопросам о восприятии относятся вопросы об объекте чувственной реальности, объекте в нирване, объекте применительно к знанию о прошлом, настоящем и будущем, знанию о соотношении сознания и речи, знанию о соотношении действия и мысли (девятая глава). Отдельно поставлен вопрос о том, образуют ли моменты сознания, связанные с чувственной реальностью, последовательность (четырнадцатая глава). Вопрос о том, возможны ли повторения в цепочке актов сознания, разбирается в отдельной беседе (двадцать вторая глава). Вопрос о том, связана ли последовательность актов сознания с созерцанием (самадхи), исследуется в одиннадцатой главе. В ней же содержатся вопросы о том, существует ли промежуточное состояние между ступенями созерцания (джханы) и можно ли в этом состоянии воспринимать окружающий мир - слышать звуки и т.д.

Далее в тексте возникает еще одна тема: возможна ли остановка сознания (ниродха-самапатти). В эту тему входят вопросы о том, является ли остановка сознания мирским или не мирским феноменом, можно ли умереть во время остановки 
сознания, ведет ли она к перерождению среди существ, не обладающих сознанием (пали асання-сатта) (пятнадцатая глава). Близка к обсуждению сознания тема внимания, в частности вопрос о том, можно ли направить внимание на несколько вещей одновременно (шестнадцатая глава).

В «Вопросах дискуссии» встречаются фрагменты, в которых разбираются вопросы буддийской этики. Основными в этой области являются понятия благого-кусала, не благого-акусала и морально не определенного-авьяката [Ложкина 2021]. Эти понятия отражены в ряде вопросов: «Имеют ли пять типов сознания моральную окраску, связаны ли сознание и сфера морали, как благое связано с пониманием и указанием на него?» Представлены и вопросы о том, могут ли за неблагими корневыми условиями мгновенно возникать благие корневые условия, т.е. данные понятия связываются с темой причинности. Понятия «благое» и «неблагое» содержатся ивв первом вопросе текста.

Помимо философско-религиозных вопросов в «Катхаваттху» входят вопросы о буддийской космологии: мирах камма-дхату (сфере кармического), рупа-дхату (сфере форм), арупа-дхату (сфере не-форм) (восьмая глава). Эта тема в более конкретном виде представлена в предыдущих главах. В частности, собеседники обсуждали проблемы о том, ведут ли жители высших сфер благочестивую жизнь брахмачарина и живут ли в этом мире животные. Относительно мира рупа-дхату спрашивают, обязательно ли ему присуща жажда форм. Выделяется вопрос об аде: «Верно ли, что в аду нет охранников и надзирателей?»

$\mathrm{B}$ «Катхаваттху» обсуждаются, по подсчетам К. Рис-Дэвидс, доктрины около 25 школ, возникших в разное время. Среди вопросов «Катхаваттху» - взгляды, не приписанные ни одной школе [Points of Controversy... 1915, XVIII-XXVII].

Составленный нами перечень вопросов «Катхаваттху» не является исчерпывающим. Мы стремились среди всех вопросов, обсуждаемых в тексте, выделить те, которые можно было бы объединить по основным тематическим блокам. Они для исследователя представляют наибольший интерес. Среди них, на наш взгляд, к самым значимым для формирования буддийской философии можно отнести вопросы о субъекте и о причинности.

В результате краткого анализа содержания «Катхаваттху» мы видим, что полный набор тем и характер их обсуждения для 
А.В. ЛОЖКИНА. «Катхаваттху» («Вопросы дискуссиш») как первоисточник... буддийской литературы уникальны. От других текстов корпуса Абхидхамма-питаки «Вопросы дискуссии» отличает диалогическая форма построения с применением особой структуры опровержения. «Катхаваттху» отличается от текстов «Винаяпитаки» и «Сутта-питаки» абстрактным уровнем изложения и использованием списков-матик. Ни один из раннебуддийских текстов не дает исследователю более полной картины развития буддизма в формате обсуждения важнейших философскорелигиозных вопросов представителями разных школ.

\section{«Вопросы дискуссии» как структурная часть палийского канона и Абхидхамма-питаки, проблема определения жанра текста}

Палийский канон - корпус священных текстов школы тхеравада. Этот корпус складывался на протяжении многих веков. Он состоит из разнородных частей. Присутствие в одном компендиуме текстов, посвященных монашеской дисциплине, нарративов о прошлых жизнях Будды, лирических произведений и доктринальных текстов может быть объяснено стремлением буддистов исчерпывающим образом собрать вместе все тексты, раскрывающие Учение с разных сторон.

Обычно считается, что палийский канон целиком был записан на Шри-Ланке на рубеже до н.э. и н.э. в виде трех разделовкорзин (пали питака). Однако можно утверждать, что ядро канона сложилось задолго до этого, а новые тексты включались в типитаку вплоть до V-VII веков н.э.

Подход к анализу текстов типитаки сегодня в исследовательской литературе не разработан до конца. Обладая большим объемом (классическое английское издание палийского канона составляет 38 томов по 400 страниц) текстов с разной тематикой и стилем, мы должны ставить вопрос о том, в чем состоит способ прочтения текста, адекватный тексту оригинала. Ответ может быть найден в анализе принципов функционирования текстопорождающей традиции раннего буддизма. Палийский канон представляет собой вариант организации текстового пространства, строго выстроенную систему текстов, в которой место каждого текста строго задано.

«Вопросы дискуссии» входят в третью часть палийского канона - Абхидхамма-питаку. Абхидхамма-питака, собрание текстов «около Дхармы» (пали абхидхамма), содержит изложение 
всех дхарм реальности. Слово «абхидхарма» (пали абхидхамма) исследователи переводят как «высшая дхарма, мета-дхарма, философская “надстройка" буддизма, создававшаяся как рационалистическая систематизация буддийской традиции» [Шохин 2011, 69], «высшее и точное учение, сущность учения, метафизика, полное объяснение» [Ronkin 2005, 36], «особая Дхарма, простая и чистая Доктрина, не предусматривающая обращения к простым людям» [Pāli-English Dictionary... 1921, 65].

В буддийской традиции обычно объясняют, что сказанное в «Сутанте» и сказанное в тексте «Абхидхармы» различается не по содержанию, а по форме. Почт. Ньянатилока пишет, что язык сутт приближен к обыденному языку (пали вохара-вачана) и понятен каждому человеку, язык же «Абхидхармы» - это философские термины, верные в абсолютном смысле (пали параматха-вачана) [Nyanatiloka 2007, 3].

Как название третьей части палийского канона слово «абхидхарма» встречается только в цейлонских хрониках и комментариях. В рамках палийской традиции абхидхамма трактуется как разъяснение значения сутр.

Абхидхамма-питака школы тхеравада состоит из семи разделов (пали пакарана): 1) «Дхаммасангани» - «Исчисление предметов учения», в нее входят классификации дхарм на обусловленные и необусловленные; 2) «Вибханга» - «Разделения», а именно три основные классификации дхарм, частично «Вибханга» повторяет «Дхаммасангани»; 3) «Дхатукатха» - обсуждения элементов; 4) «Пуггаляпанати» - классификация 386 типов личностей; 5) «Катхаваттху» - «Вопросы дискуссии»; 6) «Ямака» - «Пары», двухчастные проблемы; 7) «Паттхана» - «Причины», выделение 24 типов отношений между объектами.

Семь частей «Абхидхаммы» перечисляются комментатором Буддхагхошей. Более ранняя версия о том, сколько книг входит в «Абхидхамму», встречается в ланкийской хронике «Дипавамса». В этом тексте названы шесть книг «Абхидхаммы». Книги Абхидхамма-питаки могут перечисляться источниками в различном порядке. Считается, что истоки «Абхидхаммы» восходят к некоторым частям «Сутта-питаки» («Дасуттара-сутта», «Сангити-сутта», а также «Ангутара-никая»), в которых представлены перечни предметов учения - матики [Ложкина 2018].

В аспекте «Вопросов дискуссии» проблема отношения текста Абхидхаммы к текстам «Сутта-питаки» остается важной. 
В «Сутта-питаку» входят тексты, которые, вероятно, являются более ранними, чем «Катхаваттху» - «Катхаваттху-сутта» («Сутта о предметах беседы» или «Сутта о темах для обсуждения») и «Патхана-катхаваттху-сутта» («Первая сутта о темах для обсуждения»). «Патхана-катхаваттху-сутта», несмотря на свое название, в современной редакции палийского канона представлена после «Катхаваттху-сутты». В этих небольших cymmax речь идет о том, какие вопросы могут быть предметами обсуждения буддийских монахов. Оба текста входят в «Ангуттара-никаю» (AN 3.67 и $\mathrm{AN}$ 10.69). Эти тексты не являются изложением «Катхаваттху-ппакараны», они связаны лишь опосредованно.

«Катхаваттху-сутта» по объему больше второго текста. В первую прозаическую часть суmmы входят несколько перечней. Вторая часть cymmbl имеет стихотворную форму. Текст представляет собой поучение Буддой монахов. Темы, подходящие для дискуссии, согласно тексту, относятся к прошлому, настоящему и будущему.

Люди, подходящие и не подходящие для участия в дискуссии, определяются по трем классификациям:

1. Собеседник, подходящий для участия в дискуссии, должен давать подходящий четырем типам вопроса ответ. Типы вопросов существуют такие: вопрос, требующий категоричного ответа; вопрос, требующий аналитического ответа; вопрос, требующий уточняющего вопроса и вопрос, не требующий ответа. Не подходящий для участия в дискуссии собеседник не способен дать подходящий типу вопроса ответ.

2. Собеседник, подходящий для участия в дискуссии, должен различать четыре способа или основания ведения беседы. Не подходящий для участия в дискуссии собеседник не способен их различить. К четырем типам ведения беседы относятся ведение беседы в рамках принятого как возможное и невозможное; ведение беседы на согласованных допущениях; ведение беседы на основании учений, известных как истинные; ведение беседы по общепринятому алгоритму.

3. Собеседник не подходит для участия в дискуссии, если он переходит от одной темы к другой, уводит дискуссию от изначальной темы, проявляет злобу и неприязнь, сердится, унижает задавшего вопрос, давит на него, насмехается над ним, цепляется за его незначительные ошибки. 
Данные критерии определения того, подходит ли человек для ведения дискуссии, можно назвать этическими.

В сутmе говорится о том, что все дискуссии ведутся только ради достижения конечной цели, ниббаны, через непривязанность и постижение четырех благородных истин. Стихотворная часть сутmы повторяет прозаическую часть [Катхаваттху-сутта... 2013].

Текст «Патхама-катхаваттху-сутты» начинается с того, что днем после сбора подаяния монахи беседуют друг с другом. Вечером в зале для собраний Будда спрашивает, о чем они разговаривали. Темы, обсуждавшиеся монахами, Будда считает бесцельными и неподобающими. Это беседы о царях, о ворах, о царских министрах; об армиях, об опасностях, о войнах; о еде, о напитках, об украшениях, о постелях; о гирляндах и о благовониях; о родне, о транспорте, о деревнях, о селениях, о городах, о странах; о женщинах и о героях; о слухах с улицы и слухах у колодцев; о тех, кто скончался; о бесчисленных сплетнях; о мире, о морях; о том, чтобы стать тем или этим. Будда указывает на десять подходящих для обсуждения тем о малом количестве желаний, о довольствовании (тем, что есть), об уединении, об отсутствии связанности с другими, о зарождении усердия, о нравственном поведении, о сосредоточении, о мудрости, об освобождении, о знании и о видении освобождения. Считается, что при обсуждении любой из этих десяти тем сияние собеседников превзойдет сияние не только странствующих монахов - приверженцев других учений, но станет ярче сияния могущественных Солнца и Луны [Патхама-катхаваттху-сутта... 2013].

«Катхаваттху» помещается в корпусе «Абхидхамма-питаки» после «Пудгаляпаннати» - «Описания типов личности» (пали пуггало). Тхеравадины классифицируют понятие, которое, с их точки зрения, не обладает реальностью. Традиционно это объясняется тем, что личность или субъект существует только как понятие в обыденном словоупотреблении, а не как абсолютная сущность.

Следует обратить внимание на общие для палийских текстов и текстов Абхидхаммы особенности. Во-первых, терминологическая насыщенность языка. Буквально каждое слово стоит на строго определенном месте и нуждается в подробном комментарии. Во-вторых, обусловленная семантической нагруженностью 
А.В. ЛОЖКИНА. «Катхаваттху» («Вопросы дискуссии») как первоисточник... лексики необходимость при составлении перевода и пояснения к нему выходить на уровень интертекста и общекультурного контекста. В-третьих, работая с «Вопросами дискуссии», исследователь сталкивается с важностью анализа не только содержательной, но и формально-логической стороны текста. Первая особенность текстов абхидхаммы связана с проблемой раннебуддийских классификационных списков-матик [Ложкина 2018]. Почт. Ньянатилока называет матики взрыхленной почвой для текстов «Абхидхармы». По словам Махатхеры, матики представляют собой классификацию всего мира в психологических, этических и доктринальных аспектах [Nyanatiloka 2007, 5-7].

Еще одной особенностью «Вопросов дискуссии», выделяющей этот текст среди других текстов третьей корзины палийского канона, служит его диалогичность. Диалогическая форма «Катхаваттху» заставляет современных исследователей ставить вопрос о правомерности включения данного текста в «Абхидхаммапитаку». О. Хинюбер пишет о том, что «Катхаваттху» в соответствии с особенностями своего устройства должен входить в «Сутта-питаку»: «Не вполне ясно, почему “Катхаваттху” был включен в “Абхидхамма-питаку”. Исходя из (особенностей. - А. Л.) самого текста, включающего дискуссии, он более близок (текстам - A. Л.) сутанты, а не абхидхаммы... Причина может быть хронологической. Ко времени, когда в эпоху Ашоки “Катхаваттху” оформился, 4 великие никаи (разделы “Сутта-питаки”. - A. Л.) могли быть уже (полностью. - $A$. Л.) собраны, в то время как (корпус. - A. Л.) абхидхаммы оставался открытым» [Hinüber 1996, 73]. В рамках буддийской традиции принято подчеркивать, что «Вопросы дискуссии» относятся к Слову Будды (пали Буддха-вачана).

Среди текстов Абхидхамма-питаки «Вопросы дискуссии» выделяет еще одна черта. К. Норман пишет о том, что в «Вопросы дискуссии» входит больше цитат из палийского канона, чем в другие канонические тексты [Norman 1983, 105].

Организация композиции «Катхаваттху» - существенная проблема. Диалог в тексте касается не просто теоретических положений. Данные положения являются для раннего буддизма сакральными. Вместе с тем важно уделить внимание построению «Катхаваттху» потому, что в дальнейшем использующийся в тексте метод ведения дискуссии станет образцовым для выстраивания полемических текстов древнеиндийской философии [Ложкина 2017]. 
Мы предлагаем относить «Вопросы дискуссии» к жанру религиозно-философского диалога, отличного и от остальных недиалогичных текстов Абхидхаммы, и от диалогов «Суттапитаки», которые носят менее теоретический и абстрактный характер. Тексты Абхидхамма-питаки палийского канона разнородны как по времени создания, так и по кругу вопросов, которые в них обсуждаются. Абхидхамма представляет собой не только собрание палийских текстов, но и особый способ философствования, свойственный раннему буддизму.

\section{Выводы}

Главный вопрос, который мы задаем себе при работе с текстами палийского канона - на каких основаниях и при каких условиях возможно составление перевода сакрального буддийского текста. «Каттхаваттху» в этом отношении является интересным объектом для исследования, представляющим раннебуддийскую философию во всей ее сложности, многогранности и полноте.

«Катхаваттху» фиксирует процесс оформления интерпретации Учения, принадлежащий ныне широко распространенной школе тхеравада, и отстаивание этой школой своей интерпретации основных доктринальных вопросов перед представителями других школ. Уникальность и ценность «Вопросов дискуссии» состоят в том, что данный текст демонстрирует возможные линии развития философии раннего буддизма. С позиции историка философии интересно наблюдать, как строится палийский текст и оформляется его структура. В настоящей статье нами рассмотрены история сложения «Вопросов дискуссии», основные особенности этого текста и дан краткий анализ его содержания.

«Катхаваттху» представляет собой образец оформления религиозно-философских дискуссий школ раннего буддизма, своего рода модель их построения. Текст связан с оформлением теоретического учения о школах в раннем буддизме. Он фиксирует важные расхождения в интерпретации доктринальных вопросов между школами. В то же время структура текста позволяет не только провести всестороннее обсуждение каждого вопроса, но и включать в текст появляющиеся новые вопросы.

Философская проблематика «Катхаваттху» посвящена таким важным темам, как субъект, причинность, восприятие и др. Отделять философскую проблематику трактата от религиозной 

было бы упрощением, излишней схематизацией, чуждой тексту оригинала. Все основные темы раннебуддийской философии рассмотрены в трактате в полемической форме, каждая из точек зрения подвергается тщательной проверке. «Катхаваттху» из разрозненных обсуждений спорных вопросов в раннем буддизме на основе логического метода дискуссии создает систему, особую цельную структуру. Текст, таким образом, демонстрирует нам многогранность раннебуддийской философии, показывает весь спектр вопросов, нуждающихся в дополнительном обсуждении и осмыслении, и предоставляет канву, по которой такое обсуждение может быть выстроено.

\section{ЦИТИРУЕМАЯ ЛИТЕРАТУРА}

Катхаваттху-сутта...2013-Катхаваттху-сутта:темыдлядискуссий// Буддийский центр «Тхеравада.ру». 2013. - URL: http://www.theravada. ru/Teaching/Canon/Suttanta/Texts/an3_67-kathavatthu-sutta-sv.htm

Ложкина 2017 - Ложкина А.В. К формированию древнеиндийской логики: проблемы интерпретации концепции восьми опровержений по «Катхаваттху» // Индия - Тибет: текст и интертекст в культуре. Рериховские чтения 2012-2015 в Институте востоковедения РАН / отв. ред. В.В. Вертоградова. - М.: Языки славянской культуры, 2017. C. $152-163$.

Ложкина 2018 - Ложкина А.В. Классификационные списки матики / матрики в раннем буддизме // Философский журнал. 2018. Т. 11. № 3. C. $56-71$.

Ложкина 2019а - Ложкина А.В. «Беседа о субъекте-пудгале» как философско-религиозный диалог в структуре палийского канона («Катхаваттху I.1»): диссертация ... кандидата философских наук. - М., 2019.

Ложкина 2019б - Ложкина А.В. Феномен «школа» (никая, ачариявада) в раннем буддизме // История философии. 2019. № 2. Т. 24. С. 5-18.

Ложкина 2021 - Ложкина А.В. Этикоонтология в буддизме тхеравады: дискуссия о «благом поступке» и «дурном поступке» в «Катхаваттху» I.1.200 - I.1.216 // Философия религии: аналитические исследования. 2021. Т. 5. № 1. С. 107-124.

Патхама-катхаваттху-сутта... 2013 - Патхама-катхаваттху-сутта: темы для обсуждений // Буддийский центр «Тхеравада.ру». 2013. URL: http://www.theravada.ru/Teaching/Canon/Suttanta/Texts/an10_69pathama-kathavatthu-sutta-sv.htm

Фурцева 1990 - Фуриева Л.Р. Школы раннего буддизма в Кушанскую эпоху (по материалам эпиграфических документов): диссертация ... кандидата исторических наук. - М., 1990.

Шохин 2011 - Шохин В.К. Абхидхармы тексты // Философия буддизма. Энциклопедия. - М.: Восточная литература, 2011. С. 69-75. 
Barrua 2006 - Barrua A. Kathāvatthu: A Critical \& Philosophical Study. Delhi: New Bharatiya Book, 2006.

Bastow 1996 - Bastow D. Debates on the Time in the Kathāvatthu // Buddhist Studies Review. 1996. Vol. 13. No. 2. P. 109-133.

Bhattacharya 2010 - Bhattacharya A. Kathāvatthu on the Development of the Buddhist Doctrine and Sects (thesis). - Kolkata: University of Calcutta, 2010.

Dermott 1989 -Dermott J.P. The Kathāvatthu Niyāma Debates // Journal of the International Association of Buddhist Studies. 1989. Vol. 12. No. 1. P. 139-149.

Dubbe 2005 - Dubbe S.N. Kathāvatțhu: A Unique Pāli Text // Studies in Humanities and Social Sciences. 2005. Vol. 13. No. 2. P. 1-18.

Ganeri 2001 - Ganeri J. Argumentation, Dialogue and the Kathāvatthu // Journal of Indian Philosophy. 2001. Vol. 29. No. 4. P. 485-493.

Hinüber 1996 - Hinüber O. von. A Handbook of Pāli Literature. - Berlin: Walter de Gruyter, 1966.

Kathāvatthu 1894-1897 - Kathāvatthu: 2 Vols. / ed. by A.C. Taylor. London: Pāli Text Society, 1894-1897.

Norman 1983 - Norman K.R. Pāli Literature: Including the Canonical Literature in Prakrit and Sanskrit of All the Hīnayāna Schools of Buddhism. Wiesbaden: Otto Harrassowitz, 1983.

Nyanatiloka 1988 - Ven. Nyanatiloka. Buddhist Dictionary. Manual of Buddhist Terms \& Doctrines $/ 4^{\text {th }}$ revised ed.; ed. by Nyanaponika. - Kandy: Buddhist Publication Society, 1988.

Nyanatiloka 2007 - Nyanatiloka M. Guide through the Abhdhamma Pitaka. - Kandy: Buddhist Publication Society, 2007.

Pāli-English Dictionary... 1921 - The Pāli Text Society's Pāli-English Dictionary. Part I (A) / ed. by T.W. Rhys Davids, W. Stede. - London: Pāli Text Society, 1921.

Points of Controversy... 1915 - Points of Controversy or Subjects of Discourse / tr. by S.Z. Aung, C.A.F. Rhys Davids. - London: Pāli Text Society, 1915.

Ronkin 2005 - Ronkin N. Early Buddhist Metaphysics. The Making a Philosophical Tradition. - London; New York: RoutledgeCurzon, 2005.

\section{REFERENCES}

Aung S.Z. \& Rhys-Davids C.A.F. (Eds. \& Trans.) Points of Controversy or Subjects of Discourse. London: Pāli Text Society.

Barrua A. (2006) Kathāvatthu. A Critical \& Philosophical Study. Delhi: New Bharatiya Book.

Bastow D. (1996) Debates on the Time in the Kathāvatthu. Buddhist Studies Review. Vol. 13, no. 2, pp. 109-133.

Bhattacharya A. (2010) Kathāvatthu on the Development of the Buddhist Doctrine and Sects (thesis). Kolkata: University of Calcutta.

Dermott J. P. (1989) The Kathāvatthu Niyāma Debates. Journal of the International Association of Buddhist Studies. Vol. 12, no. 1, pp. 139-149. 
Dubbe S.N. (2005) Kathāvatṭu: A Unique Pāli Text. Studies in Humanities and Social Sciences. Vol. 13, no. 2, pp. 1-18.

Furtseva L.R. (1990) Schools of Early Buddhism in Kushan Epoch (According the Epigraphic Data) (dissertation). Moscow: RAS Institute of Studies (in Russian).

Ganeri J. (2001) Argumentation, Dialogue and the Kathāvatthu. Journal of Indian Philosophy, Vol. 29, no. 4, pp. 485-493.

Kathāvatthu-sutta. Themes for Discussions. (2013) In: Theravada.ru Buddist Center. Retrieved from http:/www.theravada.ru/Teaching/Canon/ Suttanta/Texts/an3 67-kathavatthu-sutta-sv.htm (Russian translation).

Lozhkina A.V. (2017) On the Emergence of Ancient Indian Logic: Interpreting the "Eight Refutations" Concept as Presented in the Kathāvatthu. In: Vertogradova V.V. (Ed.) India - Tibet: Text and Intertext in Culture. George N. Roerich Annual International Conference at the Institute of Oriental Studies 2012-2015 (pp. 152-163). Moscow: LSR Publishing House (in Russian).

Lozhkina A.V. (2018) Classification Lists (mātikāa / mātrkāa) in Early Buddhism. The Philosophy Journal. Vol. 11, no. 3, pp. 56-71 (in Russian).

Lozhkina A.V. (2019a) "Talk on the Subject-pudgala" as PhilosophyReligious Dialogue in the Pāli Canon ("Kathāvatthu I.1") (dissertation). Moscow: RAS Institute of Philosophy (in Russian).

Lozhkina A.V. (2019b) The Notion of 'Schools' (nikāya, ācaryāvāda) in Early Buddhism. History of philosophy. Vol. 24, no. 2, pp. 5-18 (in Russian).

Lozhkina A.V. (2021) Ethic and Ontology in Theravāda Buddhism: Talks on Ethically Good and Bad Deeds in Kathāvatthu I.1.200-I.1.216. Philosophy of Religion: Analytic Researches. Vol. 5, no. 1, pp. 107-124 (in Russian).

Norman K.R. (1983) Pāli Literature: Including the Canonical Literatire in Prakrit and Sanskrit of All the Hinayāna Schools of Buddhism. Wiesbaden: Otto Harrassowitz.

Nyanatiloka. (1988) Buddhist Dictionary. Manual of Buddhist Terms \& Doctrines ( $4^{\text {th }}$ ed.; Nyanaponika, Ed. ). Kandy: Buddhist Publication Society.

Nyanatiloka M. (2007) Guide through the Abhdhamma Pitaka. Kandy: Buddhist Publication Society.

Pathama-kathāvatthu-sutta (2013) In: Theravada.ru Buddist Center Retrieved from http://www.theravada.ru/Teaching/Canon/Suttanta/Texts/ an10_69-pathama-kathavatthu-sutta-sv.htm (Russian translation).

Rhys Davids T.W. \& Stede W. (Eds.) (1921) The Pāli Text Society's PāliEnglish Dictionary. London: Pāli Text Society.

Ronkin N. (2005) Early Buddhist Metaphysics. The Making a Philosophical Tradition. London: RoutledgeCurzon.

Shokhin V.K. (2011) Abhidharma Texts. In: Stepanyants M.T. Philosophy of Buddhism. Encyclopedia (pp. 69-75). Moscow: Vostochnaya literatura (in Russian).

Taylor A.C. (Ed.) (1894-1897) Kathāvatthu (Vols. 1-2). London: Pāli Text Society (in Pāli). 